\title{
Religion as Institution and Capital: Between Freedom and Effectiveness
}

\author{
Andrey Orekhov ${ }^{1, *}$ Alexander Efimenkov ${ }^{1, a}$
}

\author{
${ }^{1}$ Department of Social Philosophy, Peoples' Friendship University of Russia, Moscow, Russian Federation \\ ${ }^{a}$ Email: efimenkov.1995@mail.ru \\ **Corresponding author. Email: orekhovandrey@yandex.ru
}

\begin{abstract}
The article is devoted to the study of the problem of religion as an institution and "religious capital" in the aspect of accumulating freedom of its accumulation and increasing the efficiency of its use. Religion is a special system of social institutions that allows people to explain and respond to what they find supernatural and sacred. Religious capital consists of ideas, dogmas, beliefs that the believer owns as his property. There are three vectors of increasing freedom, which can be associated with the accumulation of spiritual religious capital and intellectual property of the believer. In relation to the problem of "efficiency", as a rule, the principle applies: the higher the level of freedom, the higher the efficiency of the use of religious capital.
\end{abstract}

Keywords: institution, religion, religious capital, intellectual property, believer, freedom, effectiveness

\section{INTRODUCTION}

Religion is a special system of social institutions that allows people to explain and respond to what they find supernatural and sacred [1].

Religion does not cover all esoteric and magical knowledge, but only part of it: but religious knowledge can be defined as "exclusive" in relation to other types of esoteric and magical knowledge. There are three main categories of religions: 1)" world religions", belonging to which is not related to the ethnic group of the believer (Christianity, Buddhism, Islam); 2) national religions (Judaism, Hinduism, Confucianism, Shintoism, Jainism, etc.); 3) local tribal religions.

Based on the concept of Max Weber, we can offer the following classification of religions according to two main criteria: the way of salvation (mysticism or asceticism) and the place where salvation occurs (this world or the other world) ("Table I"):

TABLE I. THE WAY OF SALVATION (MYSTICISM OR ASCETICISM) AND THE PLACE WHERE SALVATION OCCURS (THIS WORLD OR THE OTHER WORLD)

\begin{tabular}{|c|l|l|}
\hline The way of salvation & \multicolumn{1}{|c|}{ This world } & \multicolumn{1}{c|}{ The other world } \\
\hline mysticism & Confucianism & $\begin{array}{l}\text { Hinduism } \\
\text { Buddhism }\end{array}$ \\
\hline asceticism & $\begin{array}{l}\text { Judaism } \\
\text { Protestantism }\end{array}$ & Catholicism \\
\hline
\end{tabular}

The institutionalization of religions is possible in two main forms: church and the sect.

The main features of church are the division into clergy and laity, as well as the presence of a developed hierarchical structure. In a sect, in contrast to church, any believer can potentially be a "priest": the sect in this regard is more democratic than church-to achieve

*Fund: Paper is partly grounded on materials of report of Andrey Orekhov A believer as a capital-owner: what new levels of freedom are derived from accumulation of religious capital? (Conference "Conceptions of Freedom in a "Post-Truth" World: Religious and Philosophical Perspectives" $\square$ Constanta, Romania, 1-3.7.2019). Travel is supported of Program "5-100" RUDN University. the priestly rank, you do not need to have any formal education and pass the ordination ritual. It is also easier for church to justify its legitimacy in the state, but for sects, especially those with a totalitarian system based on blind submission to a charismatic leader, it is much more difficult to do so - such sects are often not subject to any external control at all.

Religion in society has three main functions: communicative, psychological, and social. The communicative function is the unity of believers through their communication, designing a special, religious, solidarity; psychological function - comfort, eliminating the fear of death, establishing a kind of 
balance in thoughts of believers; the social function- the consecration of hegemony, or "chosen" of certain social groups or classes, and in General maintaining the stability of some or other social structure.

\section{II. "RELIGIOUS CAPITAL" AS A TYPE OF A CAPITAL AND PROPERTY}

Pierre Bourdieu is a French sociologist who developed a modern theory of capitals, from which the concept of "religious capital" can be derived.

According to P. Bourdieu, there are five main types of capital:

- cultural capital;

- $\quad$ social capital;

- economic capital;

- bureaucratic capital;

- symbolic capital, as a type of capital that can transform the four previous forms of capital.

According to $\mathrm{P}$. Bourdieu, a "believer" as an adherent of a religion is not just an actor in the usual sociological sense, but a so-called "habitus", a special subject that constructs its own social world and interacts with this world. Each habitus has a special stock of capital that allows it to occupy a certain social position, rank in society. Capital can be very different: economic, social, cultural, etc. Various forms of capital, as mentioned before, can be expressed in symbolic form and thus acquire the form of symbolic capital, legitimate for any habitus [2].

The next element of the social concept of $\mathrm{P}$. Bourdieu — "field" — structures the activity of habitus and turns this activity itself into a type of social "practice". The interaction of social practices and their distribution gives us a picture of the social space, and de facto - a picture of society itself.

Thus, the General scheme of P. Bourdieu looks like this:

Habitus $\times$ Capital + Field $=$ Practice

Interaction of practices $\Rightarrow$ Social space $\Rightarrow$ Society

The "believer", like a special type of habitus, also constructs its own social field and social practice in a certain way. Here, in many cases, it acts as an authority, and, consequently, as a habitus, and the believer, when, for example, talks about the social world, in reality does not just talk, but creates this world, constructs it:

"When it comes to the social world, to speak authoritatively means to do: if, for example, I authoritatively declare that social classes exist, I contribute significantly to their existence" [3].
The activity of the "believer" in this aspect is not just an expression of his economic interest, it is a kind of" game"," investment in the game", and the cultural capital, which the French social theorist talks about as the main type of resource for the" believer", can perform the role of" ball " in such a game, through which the latter interacts with other individuals as a habitus.

Religious capital, in our opinion, is combination of two types of capital:

\section{- Spiritual religious capital (SRC).}

In this sense spiritual religious capital is one of kinds of cultural (otherwise, intellectual) capital. SRC embraces different religious ideas, religious (including theological) knowledge, and dogmas, so on. I stress the following point (in connection with problem of intellectual property rights): without fail new religious ideas, religious knowledge, it can be well-known knowledge, well-known ideas.

- Symbolic religious capital, which includes transformed kinds of such capitals: economic capital, social capital, bureaucratic capital.

For any believer symbolic religious capital consists of his religious material ownership (economic capital), his connections and contacts in the religion world (social capital), his position in religion hierarchy (bureaucratic capital). But what does he mean in the religion world, if he has not some volume of SRC spiritual religious capital?

By the way, we can find excellent analysis of approach of Pierre Bourdieu to religious capital in paper of Andrey McKinnon, Marta Trzebiatowska and Christopher Brittain "Bourdieu, Capital, and Conflict in Religious Field: The Case of the 'Homosexuality' in the Anglican Communion" [4].

As authors of this paper have already pointed, in Bourdieu's theory there are three key concepts for description of religion: field, capital, and habitus:

"These concepts, and the relation between them, developed Bourdieu sketched out his sociology of religion, but he subsequently applied them (with regular modification, updating, and adaption) to variety of topics, including art and culture, the academy, education, politics, and economy" [5].

In connection with this point Andrey McKinnon, Marta Trzebiatowska and Christopher Brittain stress:

"Religion has increasingly become differentiated, not only from the state, but also from economic field, the educational field, the scientific field, the cultural field. And so forth, each having its own species of capital. The forms of capital mat be exchangeable for religious capital, but the rate of conversion between 
capitals from different fields is historically contingent. Thus the recognition of certain forms of educational capital as legitimate or even necessary for admission to a position of influence within the religious field is a product of history of power relations, in which some forms of educational capital (such as theology degrees granted by particular institutions) have been recognized, with the value of capital continuing to shape the field" [6]

Stability of the world and national religion — such as Christianity, Islam, Buddhism, Hinduism, Confucianism, Judaism, - produce immutability of religious fields:

"Religious fields are not immutable; they differ across time and national context, as they develop historically" [7].

How capital and property are connected themselves in religion?

Besides notion "spiritual religious capital" (SRC), we can introduce another notion "religion intellectual property" (RIP).

Why for ought we to do it?

The term "capital", in contrast to notion "property", strongly amorphous and indefinite, often this term is used in different meanings. The notion "property" is more exact and definite. But if we wish to connect these two concepts, we should change our approach to understanding of intellectual property and, in part, refuse from interpretation of it in strictly juridical sense as IPR — intellectual property rights.

We must define intellectual property broadly — as property on any intellectual good, on any knowledge and information, understood in their ideal aspect. Herewith it absolutely is of no importance, about what intellectual good — "old" or "new"; existing in head of a subject or outside of it, in "objectivized" condition is said: "any knowledge, information or idea is intellectual property", that is "any knowledge, information or idea belonging to a believer is his intellectual property" [8].

We also have pointed out at the existence of four main types of intellectual property.

The first type is subject well-known intellectual property: knowledge, known to all or majority of people, and existing in a head of subject - a user of the intellectual property (for instance, formula "God exists" in the head of a believer).

The second type is subject innovative property: knowledge, opened by a subject, but still not promulgated by him, not overflowed the limits of his consciousness (for instance, new work on theology, new interpretation of some theological problem — until not published).

The third type is objectified well-known intellectual property: knowledge, known to all or majority of people, and existing outside the subjects, in recorded in textbook or on board (for example, dogma "God exists")

The fourth type is objectified innovative intellectual property: knowledge, ascertained by some subject and already objectified by him, i.e. fixed on paper, on magnetic disk or, for instance, proclaimed (promulgated) verbally by him. This, last, type of intellectual property quite correlates with "intellectual property" in juridical sense — if "objectification" is complemented the legal registration of the given knowledge in norms of patent law or copyright. Hence it is obviously legal science fixes only one of the four possible types of intellectual property (objectified innovative property).

Besides already adduced by us the classification of intellectual property, intellectual property could be divided into the general intellectual property and specific intellectual property. The general intellectual property is property of a subject on the universal, compulsory ("equally" binding for all), broadly available knowledge. The specific intellectual property is the property on concrete, "professional" knowledge, closely connected with the execution of some definite activity.

Exactly in such aspect, in my view, it is necessary to put the question about intellectual property of a believer — "religion intellectual property" (RIP).

This property of a scientist is formed from his general intellectual property and his specific religion intellectual property.

General intellectual property of a believer is his "general" education and qualification, intellectual habits of work and skills, indifferent to the execution of a main religion activity. Specific intellectual property of a believer is the very exclusive professional intellectual experience and intellectual qualification, which is accumulated by him during his professional life and which allows him to achieve definite professional status and to make his religion career — for example, the career of a priest.

The consumption of some religious goods we can consider as consumption of "religion intellectual property" (RIP) or spiritual religious capital" (SRC), but, I stress, in most cases, when we discuss the problem of religion consumption, the last is interpreted in broad sense - as consumption not only of spiritual or intellectual goods but also material goods.

For instance, we point out at approach of American researchers Jerry Park and Josef Baker: they connect 
between themselves "religious consumption" and "religious capital" and write the following:

"Religious consumption is not only a type of religious capital, and other types of religious capital can affect it. Religious capital entails both mastery and attachment: therefore, it can include a wide range of practices and beliefs that are congruent with religion. For example, conservative Protestants may take biblical literalism as a kind of mastery of theological convictions such a biblical inerrancy. Church attendance for Christians is generally viewed as an important practice and by extension greater attendance can be construed as great mastery of disciplinary communal participation. Religious consumption can be encouraged be these forms of religious capital" [9]

They give the next definition of "religious consumption" in broad sense:

"Religious consumption as religious capital reflects religious narratives, practices and belief of certain religious leaders and religious communities within a specific time and culture. Religious goods tell us how the sacred is mediated in that particular time and place" [10]

\section{A BELIEVER AS A CAPITAL-OWNER: NEW LEVELS OF FREEDOM DERIVED FROM ACCUMULATION OF RELIGIOUS CAPITAL}

There are three main vectors by which a believer can increase their level of freedom, relying on the accumulation of religious capital.

The first vector is related to the fundamental possibility of increasing the quality of freedom through direct accumulation of RIP and SRC: the more capital and property, the more opportunities for the believer to direct his stratification trajectory up to the highest stratum. For example, it is impossible for a simple believer to take a leading position in the institution of the "Church". To do this, he must receive an appropriate theological education: finish a Seminary, then a theological Academy, become a candidate or doctor of theology. That is, the "way up" is associated with increasing the educational level of the believer, accumulating RIP and SRC. A more complex situation is in the "sect", where the leader can be, in principle, any believer without any education, but in this case, he must show specific intellectual qualities, which can also be recorded through the accumulation of RIP and SRC.

The second vector should be interpreted in terms of "authoritative" and "authority". Increasing the level of freedom for a believer (including leading to a leadership position) can occur by increasing his power or his "authority" among believers. The following principle applies: "the more power and authority, the more freedom". The accumulation of RIP and SRC will also take place here, but it will be mediated by power and authority.

The third vector is based on the opposition of "good and evil" in "spiritual religious capital". If this capital is really spiritual, in what sense? And how can this affect the increase in the level of freedom of the believer? Here we can recall Kant's moral imperative: "Behave in such a way that the maxim of your behavior can also become a principle of universal law". If this categorical imperative is observed by the believer, then, relatively speaking, the vectors of good and freedom coincide, and the transition to the next level of morality and moral behavior automatically increases freedom for the believer: he has become freer, because he has become more moral. Again, the accumulation of RIP and SRC indirectly increases the quality (level) of the believer's freedom.

What, then, is left for efficiency in relation to the use of religious capital? In General, "efficiency" should be understood as the ratio of costs and returns in relation to a resource. RIP and SRC will be effective if their efficiency (return) increases while minimizing the cost of using them. It is likely that many typologies can be introduced here: for example, "the effectiveness of the believer's use of religious capital for himself" and the effectiveness of the believer's use of religious capital for society". We can also discuss the question of "positive efficiency of using SRC" and "negative efficiency of using SRC" (for example, if the leader of a sect inclines members of this sect to self-destruction), etc. But still, the authors of the article tend to assume that freedom and efficiency in using religious capital are mostly directly related to each other: the more freedom, the higher the efficiency, and much less often there is a case when the inverse proportionality acts: the more freedom, the less efficiency of using SRC.

\section{CONCLUSION}

As a result of our reasoning we came to the following conclusions:

Religion is a special system of social institutions that allow people to explain and respond to what they find supernatural and sacred.

Religious capital consists of ideas, dogmas, beliefs, which the believer owns as his property. The intellectual property of a believer can be defined as its ownership of all knowledge and information, which can be divided into General knowledge for all believers and specific knowledge that belongs only to this believer.

There are three main vectors by which a believer can increase his level of freedom based on the accumulation of religious capital: a) increasing the quality of freedom through direct accumulation of RIP and SRC; b) increasing the level of freedom for a 
believer can occur by increasing his power or his "authority" among believers; c) if the vectors of good and freedom coincide, and the transition to the next level of morality and moral behavior automatically increases freedom for the believer.

Freedom and efficiency in the use of religious capital are mostly directly proportional to each other: the more freedom, the higher the efficiency, and much less often there is a case when the inverse proportionality applies: the more freedom, the less efficiency of using SRC.

\section{References}

[1] A.Orekhov. Social Philosophy: the Subject, Structural Profiles and the Challenges on the Edge of XXI Century. - Moscow. URSS. 2010. - P.86-87 (in Russian).

[2] P.Bourdieu. The Forms of Capital // Handbook of Theory and Research for the Sociology of Education. - New York. Greenwood Press. 1986. - P.241-258.

[3] P.Bourdieu. Structures. Habitus. Practices // Contemporary Social Theory: Bourdieu, Giddings, Habermas. - Novosibirsk, Novosibirsk State University. 1995. - P.23. (in Russian).

[4] A.McKinnon, M.Trzebiatowska, C.Brittain. Bourdieu, Capital, and Conflict in Religious Field: the Case of the 'Homosexuality' in the Anglican Communion // Journal of Contemporary Religion. 2011. Vol.26. No.3.

[5] A.McKinnon, M.Trzebiatowska, C.Brittain. Bourdieu, Capital, and Conflict in Religious Field: the Case of the 'Homosexuality' in the Anglican Communion // Journal of Contemporary Religion. 2011. Vol.26. No.3. P.356.

[6] A.McKinnon, M.Trzebiatowska, C.Brittain. Bourdieu, Capital, and Conflict in Religious Field: the Case of the 'Homosexuality' in the Anglican Communion // Journal of Contemporary Religion. 2011. Vol.26. No.3. P.359.

[7] A.McKinnon, M.Trzebiatowska, C.Brittain. Bourdieu, Capital, and Conflict in Religious Field: the Case of the 'Homosexuality' in the Anglican Communion // Journal of Contemporary Religion. 2011. Vol.26. No.3. P.361.

[8] A.M.Orekhov. Intellectual Property (the Experience of SocialPhilosophical and Social-Theoretical Research. Moscow. URSS. 2009. (in Russian).

[9] J.Park, J.Baker. What Would Jesus Buy: American Consumption of Religious and Spiritual Material Goods // Journal for the Scientific Study of Religion (2007), 46 (4). P. 503.

[10] J.Park, J.Baker. What Would Jesus Buy: American Consumption of Religious and Spiritual Material Goods // Journal for the Scientific Study of Religion (2007), 46 (4). P. 502 